\title{
Obituaries
}

\section{JOHN FRANCIS HUMPHREYS JONES}

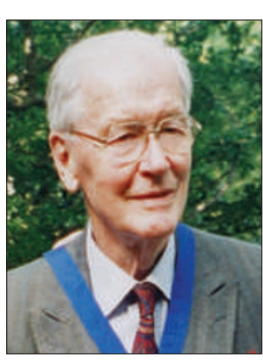

Francis Humphreys Jones died on 12 April 2010 aged 91, having enjoyed an interesting and happy life. Born in 1918 in Llanfaglan, Caernarfon, eldest of three brothers,

his father, a farmer, died when Francis was seven. His mother moved from the farm and brought the boys up in Rhos on Sea.

Educated at Ruthin School, he excelled at sport and became Deputy Head Boy. He studied dentistry at Liverpool University and immediately after qualifying volunteered to join the Royal Navy in 1941. Whilst stationed at HMS Glendower, he was responsible for ensuring the dental fitness of the seamen before duty at sea. It was during this time that he met his future wife Mair, to whom he was happily married for 56 years until her sudden death in 2002.

He served on HMS Sheffield during World War II as Surgeon-Lieutenant (D). The light cruiser was involved in the landings at Salerno and later in the Battle of North Cape and the sinking of the German battleship Scharnhorst.

At Scapa Flow in May 1944 he was selected as the Officer to represent the Sheffield to dine in the admiral's cabin of the battleship Duke of York with the King. He recently received three commemorative medals from the Russian government for his role in the Atlantic convoys shipping supplies to wartime USSR.

After the war, he returned to Caernarfon where he practised as a general dentist for nearly 40 years with a special interest in prosthetics. Known for his courteous and unhurried chairside manner, he was held in high esteem by his numerous patients.

He was High Sheriff of Caernarfonshire 1970-1971 and a past President of Y Gymdeithas Ddeintyddol (Welsh Dental Society) 1999-2002.

He was proud of his Welsh heritage and was President of the Caernarfon Civic Society and successfully ensured the preservation of some of the town's unique historic buildings.

Farming was his favourite mode of relaxation following a long day at his surgery. He was adept at lambing and haymaking on his farm and planting trees by the river Seiont.

He leaves two daughters and two grandchildren.

W. O. Roberts, W. J. Parry

\section{DUGALD CAMPBELL}

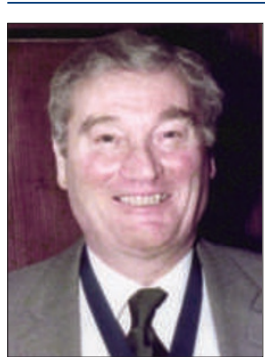

Dugald Campbell died in Ocean Grove, Victoria, Australia on 29 March 2010. Born in Glasgow in 1927 he became a dental student at Glasgow in 1946 and qualified LDS RFPS Glasgow in 1950.

After National Service in the RAF Dental Branch, Dugald returned to Glasgow working as a principal in NHS general dental practice in Bridgeton from 1952-1965 and then in the School Health Service from 1965-1974.

Dugald was a highly respected and successful dental surgeon but in 1974 a new challenge presented itself when the Community Dental Service was created. He was appointed Assistant Chief
Obituaries should be submitted by email to Kate Maynard at k.maynard@nature.com.

All submitted obituaries should be 350 words maximum in length (apart from obituaries for past presidents of the BDA where the length should be $700-800$ words) Content of the obituary is down to the individual author, and the approval of the family should be given for the obituary prior to submission to the $B D J$.

Administrative Dental Officer (ACADO) to the Greater Glasgow Health Board, the largest in Scotland. There, working with his good friend and colleague, the CADO Bob MacKechnie, he developed his interest and skills in administration. He was especially involved with the Glasgow Dental Hospital \& School, the development of regional clinics and outreach teaching for dental students.

His infectious enthusiasm, constructive approach and determination led to many improvements in dental health and education. He was also an important member of the team which organised the Celebration of the Centenary of the Glasgow Dental Hospital and School in 1979 and of the subsequent appeal which funded the West of Scotland Centre for Postgraduate Dental Education which was opened in 1987.

In 1985/6, Dugald was President of the Community Dental Services Group of the BDA. He was also President of the Glasgow Dental Alumnus Association.

In 2005, after Dugald was afflicted with Parkinson's Disease, he and his wife, Deirdre, left Scotland to continue their retirement in Australia where they were reunited with their daughters, Debbie and Lorna and their families, and where Dugald died recently. He is also survived by his son, Colin.

Dugald's former colleagues and friends remember with gratitude his many contributions to dentistry in the West of Scotland.

David Mason, Bill Smith 